\title{
Dermal lip protuberances associated with aquatic surface respiration in juveniles of the piscivorous characid Salminus brasiliensis (Actinopterygii: Characidae)
}

\author{
Pablo A. Scarabotti ${ }^{1,2}$, M. Julieta Parma ${ }^{1,3}$, Javier A. López ${ }^{1,2}$ and Romina Ghirardi ${ }^{1,4}$
}

Some South American freshwater fishes can improve their capability of aquatic surface respiration (ASR) by developing dermal lip protuberances in the lower jaw. This adaptation was thought to be limited to omnivorous or herbivorous fishes. The present work provides the first evidence that juveniles of a piscivorous characid, Salminus brasiliensis, develop dermal lip protuberances during periods of hypoxia in floodplain ponds of the Salado River, in Argentina. The protuberance of S. brasiliensis involves dermal portions of both jaws exhibiting lateral lobes on the sides of the mouth arranged in the vertical plane. Water dissolved oxygen concentrations less than or equal to $1.05 \mathrm{mgl}^{-1}$ were associated with a remarkable increase in lip protuberance. The lateral lobes of the protuberance in this species may limit the access of water to the anterior portion of the mouth which is positioned nearer to the oxygenated surface water during ASR. Finally, ASR, complemented with the development of dermal lip protuberances, can be considered a valuable strategy to survive in hypoxic environments, even for carnivorous fishes with elevated oxygen requirements.

Alguns peixes de água doce da América do Sul podem melhorar o desempenho da respiração aquática superficial (RAS) desenvolvendo protuberâncias dérmicas labiais na mandíbula. Considerava-se que essa adaptação era limitada aos peixes onívoros ou herbívoros. Este trabalho apresenta os primeiros indícios de que juvenis de um caracídeo piscívoro, Salminus brasiliensis, desenvolvem protuberâncias dérmicas labiais durante períodos de hipoxia em lagoas de várzea do rio Salado, Argentina. As protuberâncias de S. brasiliensis envolvem porções dérmicas das duas mandíbulas e exibem lóbulos laterais ao lado da boca dispostas no plano vertical. Concentrações de oxigênio dissolvido na água, inferiores ou iguais a 1,05 $\mathrm{mgl}^{-1}$, foram associadas a um aumento notável no desenvolvimento das protuberâncias labiais. Nesta espécie os lóbulos laterais da protuberância podem limitar o acesso de água à porção anterior da boca, que está posicionada mais perto da superfície da água oxigenada durante a RAS. Finalmente, a RAS, complementada com o desenvolvimento de protuberâncias dérmicas labiais, pode ser considerada uma valiosa estratégia para a sobrevivência em ambientes hipóxicos, mesmo para peixes carnívoros com elevada demanda de oxigênio.

Key words: Hypoxia, Morphological adaptation, Lip extension, Floodplain pond, Argentina.

\section{Introduction}

Aquatic surface respiration (ASR) is a widespread behavioral mechanism in freshwater fishes that allows the utilization of the relatively oxygen-rich surface water in contact with the atmosphere during environmental hypoxia (Kramer \& Mehegan, 1981; Kramer \& McClure, 1982; Soares et al., 2006). Some South American freshwater fishes improve
ASR performance by developing a swelling in the lower lip (Braum \& Junk, 1982; Saint-Paul \& Soares, 1988; Winemiller, 1989; Val \& Almeida-Val, 1995). The lip swelling does not have a gas exchange function, but it has been hypothesized that it prevents the mixture of the surface water with the hypoxic water just beneath (Val et al., 1998) and by changing the mouth opening to a more up-turned position, a better design to perform ASR (see Lewis, 1970).

\footnotetext{
${ }^{1}$ Instituto Nacional de Limnología, José Maciá 1933, 3016 Santo Tomé, Santa Fe, Argentina. pascarabotti@yahoo.com.ar ${ }^{2}$ Universidad Autónoma de Entre Ríos, Facultad de Ciencia y Tecnología, Andrés Pazos y Corrientes, (3100) Paraná, Argentina. ${ }^{3}$ Universidad Nacional del Litoral, Facultad de Humanidades y Ciencias, Paraje el Pozo s/n, (3000) Santa Fe, Argentina.

${ }^{4}$ Instituto de Botánica ‘Carlos Spegazzini'. Avenida 53 477, (1900) La Plata Buenos Aires, Argentina.
} 
To date, dermal lip protuberances associated with environmental hypoxia are known for at least twenty species of South American Characiform fishes (Braum \& Junk, 1982; Saint-Paul \& Soares, 1988; Winemiller, 1989; Casciotta, 1995; Val \& Almeida-Val, 1995). Winemiller (1989), in examining the dermal lip protuberances in fourteen Venezuelan species, observed that this trait was restricted to herbivorous and omnivorous fishes and argued that the structure of this adaptation could impose limitations on the hunting activity of piscivorous species during prey capture.

The "dorado", Salminus brasiliensis, is one of the largest predators occurring in the Paraná River basin, reaching in some cases $1 \mathrm{~m}$ in standard length (Britski et al., 1999). The genus Salminus includes predatory salmon-like fishes (Géry, 1977). Salminus brasiliensis is a very active fish, characterized by having high metabolic rates with elevated oxygen consumption per unit mass (Parma de Croux, 1997). Juveniles specialize in piscivory very early in development (Rossi, 1989). Adults generally occur in the main channel, but larvae and juveniles can enter the floodplain during inundation (Menni, 2004; Rossi et al., 2007), where they can experience hypoxic conditions.

During an annual study of fish populations in an affluent of the middle Paraná River in Argentina, several individuals of $S$. brasiliensis were collected from environments with strong oxygen depletion $\left(<1 \mathrm{mgl}^{-1}\right)$. This work presents evidence that juveniles of the piscivorous fish $S$. brasiliensis are capable of developing dermal lip swellings during periods of environmental hypoxia. The relationship between water dissolved oxygen and quantitative measurements of lip protuberance is also described.

\section{Material and Methods}

Sampling was carried out with seine nets (10 m length, $5 \mathrm{~mm}$ mesh) every month from March 2004 to September 2005, in semipermanent floodplain ponds in the Salado River, $2 \mathrm{~km}$ upstream of the confluence with the Paraná River (3139'46”'S $60^{\circ} 45^{\prime} 06^{\prime \prime} \mathrm{W}$ ) (Fig. 1). Sampling was standardized by the number of netting bouts ( 1 to 3 ) performed in each pond. In each netting bout, we covered an area of approximately $200 \mathrm{~m}^{2}$. Individuals of S. brasiliensis were captured only in March and April 2004 and from December 2004 to March 2005 in the floodplain areas sampled, probably because of the migratory and reproductive cycles exhibited by this species at this point of La Plata basin (see Bechara et al., 2001). Specimens were preserved in 10\% formalin for a period of one year and transferred to $70 \%$ ethanol, prior to the processing of the material. The material analyzed was deposited in the fish collection of the Instituto Nacional de Limnología (INALI) of Argentina, under the catalogue numbers 1259, 1271, 1375, 1387, 1418 and 1605. Dissolved oxygen and temperature were measured near the center of each pond at $20 \mathrm{~cm}$ depth with a YSI model 57 oxygen meter and with a mercury thermometer, respectively. To avoid bias produced by daily variation, oxygen levels were taken between 900 and $1100 \mathrm{hr}$, synchronously with fish sampling.

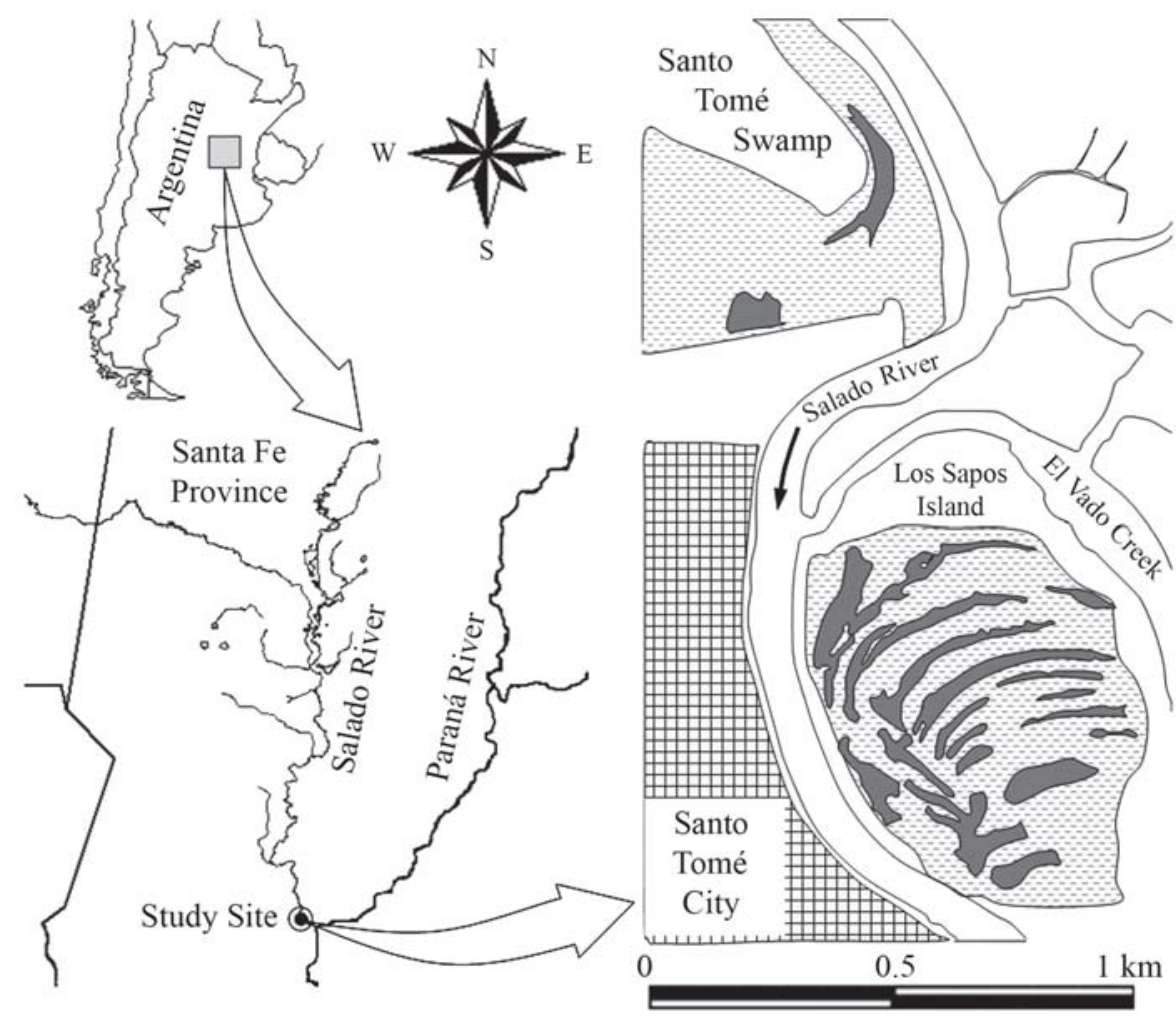

Fig. 1. Map showing the location of Salado River in Santa Fe Province (Argentina) (left) and inset showing the study region (right). Shaded sectors indicate floodplain areas containing the sampled lakes. 
Lip measurements were performed in seventy-six juveniles $S$. brasiliensis (standard length; mean \pm SD, $92 \pm$ $42 \mathrm{~mm}$, range $47-176 \mathrm{~mm}$ ) with a digital caliper to the nearest $0.01 \mathrm{~mm}$. Lip width at the middle line of distal tip of lower jaw (LW) was calculated as the distance between the outer face of tooth row and the rostral border of the lip (Fig. 2). Maximum lip width (MLW) was registered at the point with greatest lip development in the lower jaw over a line perpendicular to the tooth row. Since lip protuberances can become folded during preservation, fish were positioned over a glass plate to acquire an unfolded aspect before measurements.

In order to determine the relationship between lip extension and mouth shape, the longitudinal dimension of the mouth was measured in eight individuals with fully developed lip protuberances and eight individuals with normal lips. This variable was quantified as the distance between the mouth corner (the point of contact between upper and lower lip) and the snout tip in the upper jaw, at a standardized mouth opening of $2 \% \mathrm{SL}$ (presumed to be a mean mouth opening in a fish performing ASR).

Serial cross-sections of the lateral portion of the lower lip were prepared from specimens both with and without lip development. Histological sections were stained with hematoxylin-eosin (Presnell \& Schreibman, 1997) and examined with a Nikon 75256 microscope.

Both ML and MLW were divided by SL in order to eliminate differences in morphology due to size. All comparisons and relationships were calculated using these standardized variables. To determine how these two morphological variables covaried during lip development, ML was regressed against MLW using linear regression. The relationship between the ML and MLW values of each fish and oxygen concentration from the corresponding sample were determined by linear regressions. The longitudinal dimension of the mouth in individuals with lip protuberances and individuals with a normal lip was compared using Student's t-test.

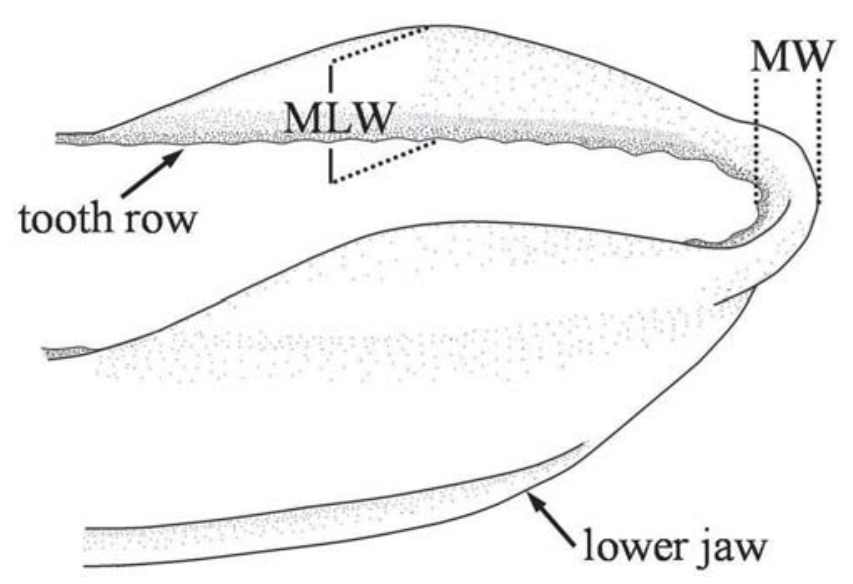

Fig. 2. Measurements taken in the lower jaw of S. brasiliensis. LW: Median lip width, MLW: Maximum lip with.

\section{Results}

The dermal lip extension exhibited by $S$. brasiliensis consisted of a lip broadening all around the lower jaw that displayed a flattened lateral lobe directed dorsally (Fig. 3). The lower lip also showed an anterior enlargement at the tip of the lower jaw by which fish exhibited a slightly prognathic aspect. The upper jaw showed a similar but subtler lip enlargement consisting of a flattened projection that affected only the lateral portion of the upper lip from the anterior end of the maxillary bone to approximately the mid-point of its length (Fig. 3). Due to the shape of the lower lip protuberance, maximum lip width occurred generally at the sides of the mouth. The microscopic examination of dermal lip protuberances showed extensive oedema in the stratum spongiosum, with interstitial spaces significantly larger compared to sections of normal lips (Fig. 4). The lateral lobe of the protuberance was observed as a membranous projection from the lip corner and possessed a thinner epidermis. No unusual proliferation of blood vessels was observed.

Minimal values of dissolved oxygen were detected in February coincident with the maximum hydrological level, but only one individual was captured during this time. Fish exhibiting lip protuberances were observed exclusively in December 2004 and January 2005 and exclusively during periods of strong oxygen depletion (Fig.5). Numerous small fishes were observed skimming the surface water on these sampling dates (presumably performing ASR), although species identities could not be determined. Water temperature of the floodplain site was (mean \pm SD) $27 \pm 0.45^{\circ} \mathrm{C}$ for December samples and $30 \pm 0.85^{\circ} \mathrm{C}$ for January samples.

The values of MLW were inversely correlated with dissolved oxygen (linear regression, $R^{2}=0.22, p<0.0001$; Fig.6) but did not show any association with water temperature (linear regression, $R^{2}=0.009, p=0.451$ ). Maximum lip width did not show appreciable responses at oxygen concentrations between 4.6 and $1.4 \mathrm{mgl}^{-1}$ (corresponding to $57 \%$ and $19 \%$

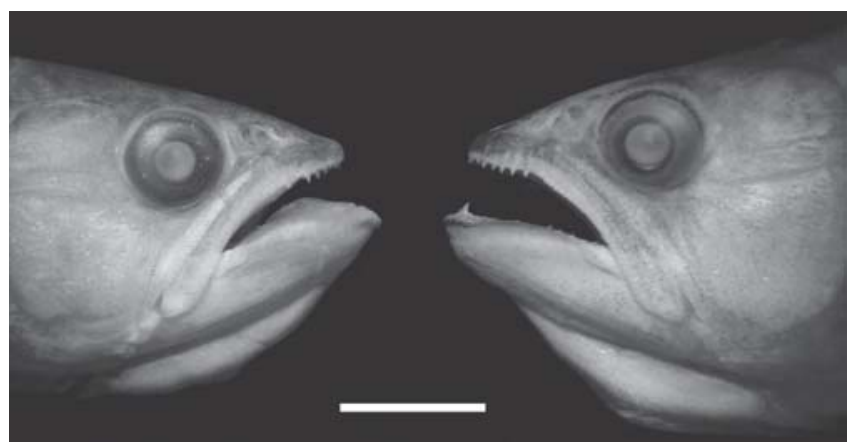

Fig. 3. An individual of $S$. brasiliensis exhibiting the lip extension (left), and another individual showing typical lip morphology (rigth). Both fishes show a similar mouth opening. Protuberances can be seen in both jaws covering the tooth rows, which are evident in the individual with typical lip morphology. Scale bar $=1 \mathrm{~cm}$. 


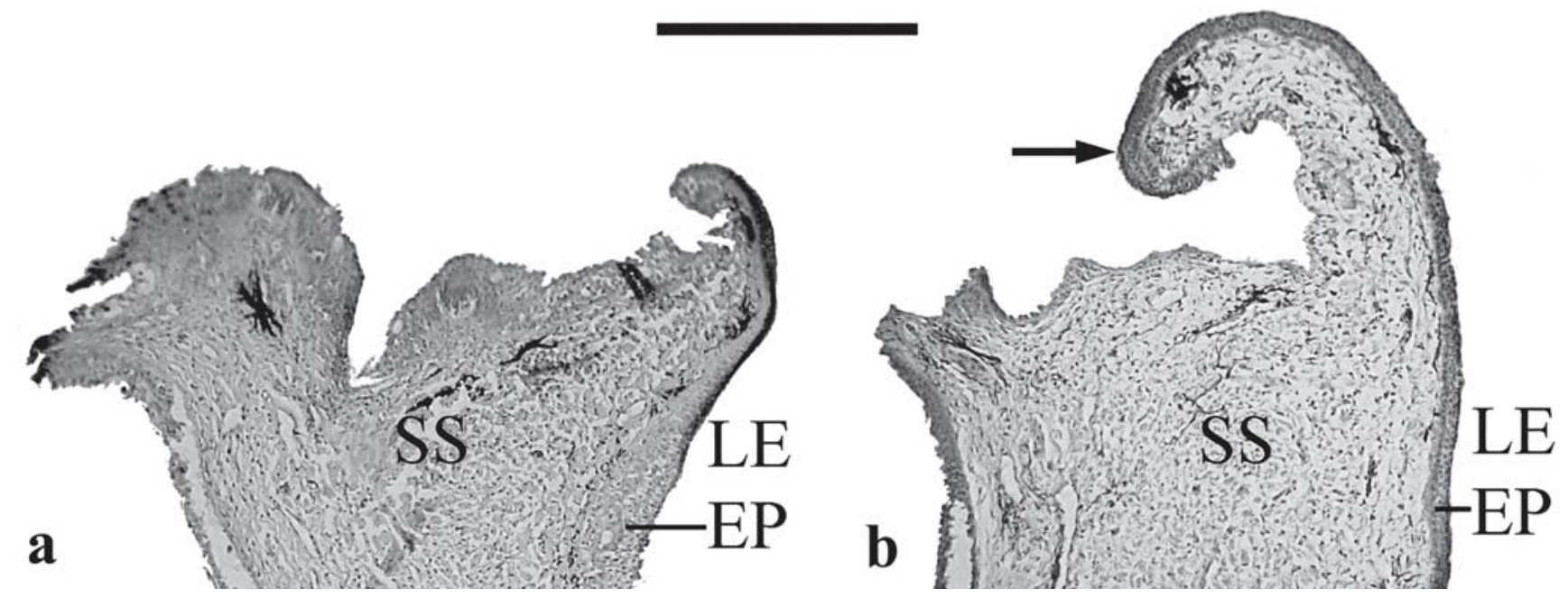

Fig. 4. Transversal cross-section of the lateral portion of lower lip from an individual of Salminus brasiliensis, (a) with typical lip and (b) with dermal lip protuberance. $\mathrm{EP}$ = epidermis, SS = stratum spongiosum, LE = lateral edge, arrow indicates the lateral lobe of the dermal lip protuberance. Scale bar $=0.25 \mathrm{~mm}$.

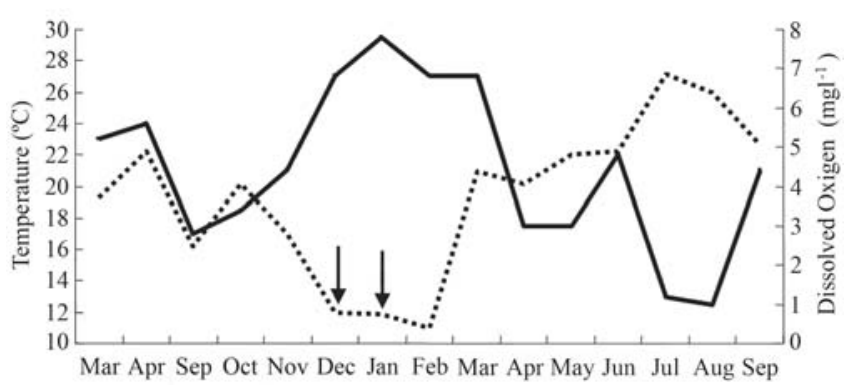

Fig. 5. Mean monthly water temperature (solid line) and dissolved oxygen (dotted line) at the floodplain site of Salado River sampled during 2004 and 2005. Arrows indicate the dates with occurrence of individuals with dermal lip protuberances.

dissolved oxygen saturation) but increased noticeably at concentrations below $1.05 \mathrm{mgl}^{-1}$ (below $13 \%$ saturation) (Fig. $6)$. The largest fish observed with a fully developed protuberance was $92 \mathrm{~mm}$ SL. During lip development, ML increased at a rate of $0.65 \mathrm{MLW}$, that is to say, lateral lobes grew faster than the rostral portion of the lip (linear regression, $\left.R^{2}=0.649 ; p<0.0001\right)$. The longitudinal dimension of the mouth was significantly shorter in individuals exhibiting lip protuberances in comparison with individuals with typical lips (Student's $t$-test, $t=-9.729, p<0.0001$ ) leading to a reduction in $66 \%$ of the mean mouth size. These two groups of individuals did not differ significantly in SL (Student's $t$ test, $t=1.152, p=0.269$ ).

\section{Discussion}

The results show that juveniles of $S$. brasiliensis are capable of developing dermal lip protuberances during periods of extreme hypoxia that occur in floodplain environments. The

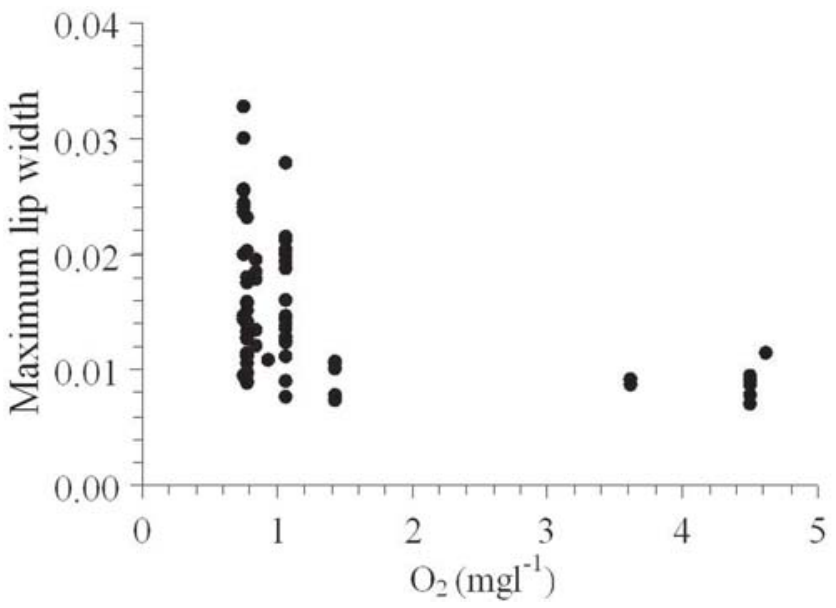

Fig. 6. Relationship between MLW (maximum lip width) and water dissolved oxygen. Values of lip size are expressed as proportions of standard length of the body.

protuberance of $S$. brasiliensis is quite different from those described in other fishes (Braum \& Junk, 1982; Winemiller, 1989; Casciotta, 1995). Small characids, gasteropelecids (Winemiller, 1989) and serrasalmids (subfamily Myleinae) (Braum \& Junk, 1982; Saint-Paul \& Soares, 1988) have relatively small mouths that are limited posteriorly by a very curved maxillary bone. Lip protuberances in these species consist of an anterior or anterolateral expansion of the lower lip occurring in a horizontal plane. In contrast to the above described species, the protuberance of $S$. brasiliensis includes lateral lobes in both jaws that develop in a vertical plane. This species has a slightly curved maxillary bone that reaches the mouth corner posteriorly and defines a proportionally wider mouth. When performing ASR in hypoxic environments, the posterior portion of the large mouth of $S$. brasiliensis with a typical lip remains at a considerable distance from the water surface (Fig. 7a). This morphology may be 
unfavorable for selectively drawing surface water into the mouth, as was observed by Lewis (1970) for Micropterus salmonides, because it allows the access of hypoxic water from the lower layers.

In this context, the singular morphology of the protuberance of $S$. brasiliensis could be interpreted as a way to reduce the disadvantages imposed by large mouth size in the performance of ASR. As we observed, fishes with fully developed protuberances showed significant reductions in mouth size. The lateral lobe dorsally directed from the lower jaw and the minor lobe of the upper jaw cover the posterior half of the mouth, reducing its size. As a result, the entrance of water during inspiration is limited to the anterior portion of the mouth nearer to the more-oxygenated surface water (Fig. 7b).

Lip protuberance development showed a non-linear relationship with respect to dissolved oxygen, showing no appreciable responses at oxygen concentrations greater than $1.4 \mathrm{mgl}^{-1}$. Concentrations less than or equal to $1.05 \mathrm{mgl}^{-1}$ were associated with a remarkable increment in lip extension. These values are similar to those observed in Venezuelan characids that exhibited lip protuberances at oxygen concentrations less than or equal to $1.4 \mathrm{mgl}^{-1}$ (Winemiller, 1989). However, a broad variation in the response to dissolved oxygen was observed even at concentrations as low as $0.75 \mathrm{mgl}^{-1}$. These samples contained fish at all stages of lip development, from typical lips to ones with fully-developed protuberances. This pattern was observed as well by Winemiller (1989) in several fish species from caño Maraca, Venezuela. In other species, lip protuberances require at least two hours to develop (Saint-Paul \& Soares, 1988; Val et al., 1998). Fish experiencing slightly different oxygen conditions in the hours prior to capture could exhibit different lip development within a sample. This variation should increase with increasing variety of microhabitats with different oxygen concentrations available to fish within a water body. Actually, high water samples in December, when fish may move freely to the main channel to reach better oxygen conditions, showed the greatest variation in lip development.

Juveniles of $S$. brasiliensis are very active fish that show high metabolic rate with elevated routine oxygen consumption (Parma de Croux, 1997). These characteristics are generally encountered in species with little tolerance to hypoxic conditions. In this study, juveniles of $S$. brasiliensis were collected in waters with dissolved oxygen concentration as low as $0.75 \mathrm{mgl}^{-1}$ at a temperature of $31.5^{\circ} \mathrm{C}$. Nearly all individuals contained food in their stomachs, were very active at the time of collection, and did not show signs of oxygen depletion. Since alternative breathing adaptations (such as air breathing) are not known to happen in this species, ASR, complemented by the development of dermal lip protuberances, can be considered a valuable strategy that permit survival in hypoxic environments, even for species with elevated oxygen requirements. This idea is supported by the observation that Colossoma macropomum performing ASR in hypoxic waters can restore blood physiological variables (e.g., organic phosphate concentrations) to levels similar to those observed in fish kept under normoxic conditions, suggesting that a fish can extract almost normoxic water by means of ASR (Val et al., 1998).

Winemiller (1989) suggested that lip extension could impose limitations on the mode of feeding in piscivorous fishes and hypothesized that this trait could be adaptive only for herbivorous and omnivorous surface-feeding characids. Salminus brasiliensis is a largely carnivorous fish from very early on development (Rossi, 1989). Dermal lip protuberances could diminish prey capture efficiency or could be damaged during prey capture and handling. However, we observed that nearly all specimens analyzed had prey items in their stomachs and did not have wounds on their lips. Lip swellings are temporary structures taking about 2 to 3 hours to develop, remaining during hypoxic conditions and taking about the same time to disappear as soon as normoxic conditions are reestablished. Fish could be selectively concentrating their feeding activities during normoxic periods when lips are not developed, preventing this adaptation from interfering with predatory behavior.

Braum \& Bock (1985) reported that another piscivorous
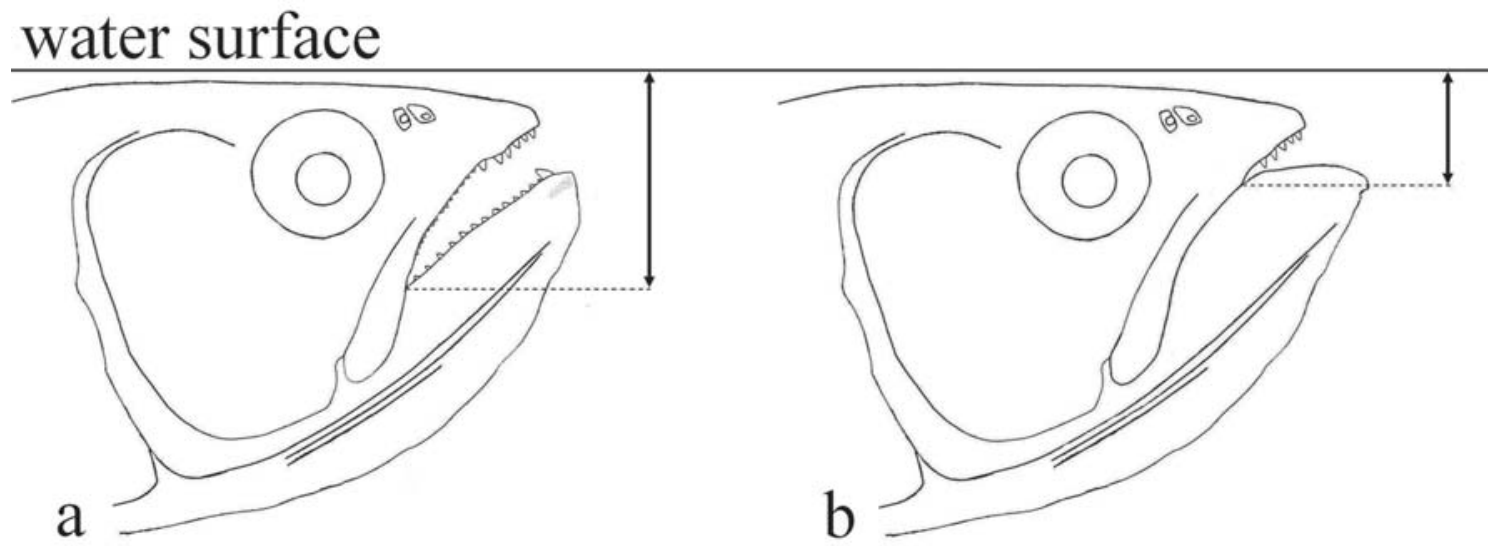

Fig. 7. Relative position of the mouth corner in the water column during ASR in an individual of S. brasiliensis with typical lip (a) and another with lip protuberances (b). The drawing represents individuals with smaller mouth opening than those of Fig. 1, so that lateral lobes of the protuberance come in contact to cover the sides of the mouth. 
species, Osteoglossum bicirrosum, shows morphological adaptations to improve ASR performance. This species displays mentonian barbels normally folded upon the lower jaw that are deployed forward during periods of environmental hypoxia. Arranged in this way, barbels create a funnel to channel surface water to the orobranchial cavity. However, these organs are permanent structures and do not undergo the tissue modifications driving the reversible changes in size observed in dermal lip protuberances of characids (Braum \& Junk, 1982, Saint-Paul \& Soares, 1988). Thus, S. brasiliensis is the first piscivorous species reported to exhibit reversible dermal lip structures to facilitate ASR.

In this work, lip development is reported only for juvenile fish. Juveniles and adults of $S$. brasiliensis show a differential distribution along the transversal dimension of the river, where the former are more frequently found in the floodplain ponds and the latter found almost exclusively in the main channel (Rossi et al., 2007). Due to their smaller body size, juvenile animals are vulnerable to a broader range of predators than adults, suffering proportionally stronger selective pressures for avoiding predation (Werener, 1986). As larger predatory fishes tend to avoid hypoxic conditions, floodplain areas can function as refuges from predation (Anjos et al., 2008; Chapman \& Chapman, 1998). To inhabit these environments, juvenile fish have to possess adaptations to survive under the extremely hypoxic conditions in floodplain ponds. On the other hand, larger body size protects adults from predators, but it is also associated with a reduction in the performance of ASR as the fish grow (Lewis, 1970). These changes in performance during ontogeny would induce larger $S$. brasiliensis to avoid hypoxic conditions of the floodplains. In this context, we hypothesize that a trade-off between predation risk and hypoxia would be regulating, at least partially, the differential distribution of the size classes across the transversal dimension of the river.

\section{Acknowledgments}

We thank Estaban Creus for assistance with the field work. Cristián de Bonis collaborated with the digital edition of the photographs. Déborah Carvalho kindly revised the abstract in Portuguese. We are grateful to Jimena Cazenave and two anonymous reviewers for helpful suggestions on an early version of the manuscript. Financial support for this study was provided by the Instituto Nacional de Limnología of Argentina and by doctoral fellowships to PAS, JAL and RG, by CONICET, Argentina.

\section{Literature Cited}

Anjos, M. B., R. R. de Oliveira \& J. Zuanon. 2008. Hypoxic environments as refuge against predatory fish in the Amazonian floodplains. Brazilian Journal of Biology, 68: 45-50.

Bechara, J. A., J. P. Roux, J. C. Terraes, S. Sánchez, P. Toccalino \& A. González. 2001. Ciclos de abundancia de los principales peces de importancia económica del Alto Paraná.
Comunicaciones Científicas y Tecnológicas. Universidad Nacional del Nordeste, Corrientes, Argentina.

Braum, E. \& W. J. Junk. 1982. Morphological adaptation of two Amazonian caracoids (Pisces) for surviving in oxygen deficient waters. Internationale Revue der gesamten Hydrobiologie, 67: 869-886.

Britski, H. A., K. Z. de S. Silimon \& B. S. Lopes. 1999. Peixes do Pantanal. Manual de identificação. Brasília, Embrapa, 184p.

Casciotta, J. R. 1995. New record of the dermal lip protuberance in characiforms from Río de La Plata Basin in Uruguay. Ichthyological Exploration of Freshwaters, 4: 79-80.

Chapman, L. J. \& C. A. Chapman. 1998. Hypoxia Tolerance of the Mormyrid Petrocephalus catostoma: Implications for Persistence in Swamp Refugia. Copeia, 1998(3): 762-768.

Géry, J. 1977. Characoids of the word. Neptune City, T.F.H. Publications, 672p.

Kramer, D. L. \& J. P. Mehegan. 1981. Aquatic surface respiration, an adaptive response to hypoxia in the guppy, Poecilia reticulata (Pisces, Poeciliae). Environmental Biology of Fishes, 6: 299-313.

Kramer, D. L. \& M. McClure. 1982. Aquatic surface respiration a widespread adaptation to hypoxia in tropical freshwater fishes. Environmental Biology of Fishes, 7: 47-55.

Lewis, W. M., Jr. 1970. Morphological adaptations of cyprinodontoids for inhabiting oxygen deficient waters. Copeia, 1970(2): 319-326.

Menni, R. C. 2004. Peces y ambientes en la Argentina continental. Monografías del Museo Argentino de Ciencias Naturales Bernardino Rivadavia, 5: 1-316.

Parma de Croux, M. J. 1997. Relationship between metabolic rate and body weight in Salminus maxillosus (Valencienes, 1840). Journal of Aquariology Tropical, 12: 17-22.

Presnell, J. K. \& M. P. Schreibman. 1997. Humason's Animal Tissue Techniques. Baltimore, The John Hopkins University Press, 572p.

Rossi, L. M. 1989. Alimentación de larvas de Salminus maxillosus (Val. 1840) (Pisces, Characidae). Iheringia, Série Zoologia, 69: 49-59.

Rossi, L. M., E. Cordiviola \& M. J. Parma. 2007. Fishes. Pp. 305325. In: Iriondo, M. H., J. J. Paggi \& M. J. Parma (Eds.). The Middle Parana River: Limnology of a Subtropical Wetland. Heidelberg, Springer-Verlag, 382p.

Paul, U. \& G. M. Soares. 1988. Ecomorphological adaptation to oxygen deficiency in Amazon floodplains by serrasalmid fish of the genus Mylossoma. Journal of Fish Biology, 32: 231-236.

Soares, M. G. M., N. A. Menezes \& W. J. Junk. 2006. Adaptations of fish species to oxygen depletion in a central Amazonian floodplain lake. Hydrobiologia, 568: 353-367.

Val, A. L. \& V. M. F. Almeida-Val. 1995. Fishes of the Amazon and their environments: Physiological and biochemical features. Heidelberg, Springer-Verlag, 224p.

Val, A. L., M. N. P. Silva \& V. M. F. Almeida-Val. 1998. Hypoxia adaptation in fish of the Amazon: a never-ending task. South African Journal of Zoology, 33: 107-114.

Werner, E. E. 1986. Amphibian metamorphosis: Growth rate, predation risk, and the optimal size at transformation. American Naturalist, 128: 319-341.

Winemiller, K. O. 1989. Development of dermal lip protuberances for aquatic surface respiration in South American characid fishes. Copeia, 1989(2): 382-390.

Accepted June 15, 2009 Published September 30, 2009 